\title{
Empowering LPDs and Cooperative Legal Entities in Supporting the People's Economic Resilience in Pemogan Village
}

\author{
Luh Putu Sudini ${ }^{1}$, Nyoman Sujana ${ }^{2}$, Nyoman Sukandia ${ }^{3}$, A.A Istri Agung ${ }^{4}$, \\ Ni Luh Made Mahendrawati ${ }^{5}$ \\ Faculty of Law, Universitas Warmadewa, Denpasar-Bali, Indonesia \\ \{Sudini_putu@yahoo.co.id $\left.{ }^{1}\right\}$
}

\begin{abstract}
Community service was carried out in Pemogan Traditional Village, South Denpasar Sub-district, Denpasar City from 30-31July 2019 through a seminar with the theme "Empowerment of the LPDs and the Cooperative Legal Entities in Supporting the People's Economic Resilience." The Village Credit Institution (LPD) and the cooperative entity in Pemogan provide benefit to the residents' welfare, through the economic potential and capability development of members and community. The purpose of community service is to determine, study, and interpret the LPD and Cooperative Entity empowerment in supporting the people's economic resilience in Pemogan Village, South Denpasar Sub-district. The problems examined are how to solve bad credit in LPD practices in Pemogan Village and the benefits associated with cooperative to the residents. Settlement of bad credit in LPD practices is initiated by negotiating between managers and the problematic residents. This is followed by finding a solution to solve the problems between residents and LPDs. The benefits of the Cooperative to the Pamogan residents are that it is able to improve the life quality of residents. It also has the ability to build and develop the potential and economic capabilities of each member, thereby, enabling them to live in prosperity.
\end{abstract}

Keywords: LPD; Cooperative Entity; People's Economic Resilience

\section{Introduction}

The People's Credit Institution (LPD) in Bali which is based on the customary law community in Pekraman Village operates to drive the rural economy and preserve customs and traditions as well as maintain the cultural continuity of the Balinese people which is imbued with Hindu teachings called Tri Hita Karana, namely three sources of happiness in dimensions a harmonious and harmonious relationship and harmony between humans and the creator of God Almighty, between humans and fellow humans, and a harmonious relationship between humans and the universe. Therefore, the life of the customary law community in Pekraman Village in Bali is always oriented towards the life world-scale (real world) and the abstract world (spiritual world - religious-magical) which is reflected in awig-awig (the form of customary law) as the basis for the establishment of the LPD in Bali. 
LPD and cooperatives in Pemogan Village are beneficial for the welfare of the Pemogan Village community, one of which is through the development and development of the economic potential and capacity of members in particular and society in general to improve the economic and social welfare of community members. Several studies related to current issues have been studied before, such as Czekaj, Adamsone-Fiskovica, Tyran, \& Kilis (2020) examined about Small farms' resilience strategies to face economic, social, and environmental disturbances in selected regions in Poland and Latvia. Then, Alves, Ferreira, \& Araújo (2019); Hayter \& Nieweler (2018); Pomeroy, Arango, Lomboy, \& Box (2020) discussed about resilience economic as well as cooperative resilience (Borda-Rodriguez \& Vicari, 2014). Likewise, this present study in a different object and site of research aims to analyze how problematic credit solutions are in the LPD practice in Pemogan Village and find out how cooperatives benefit the Pemogan Village community.

\section{Results and Discussion}

\subsection{Village Credit Institutions (LPD) The}

LPDs, in carrying out their functions, use the banking financial management pattern. However, from the perspective of background, concept and orientation, LPD is not a bank, or in fact it cannot be compared to a bank at all. The basis of the argument is (1) LPD does not manage public funds at all, but community funds (Desa Pekraman); (2) LPD does not operate in public areas at all, but is limited to community areas (pekraman village); (3) LPD has absolutely no orientation to the public interest, or the general welfare, but rather the interests or welfare of the community; (4) LPD is not at all a capitalist individual institution which is oriented towards the profit of the individual owner of the bank's capital, but belongs to the community and is oriented towards the common interests of the community; and (5) LPD is not oriented solely to profit, but profit in the context of carrying out the Pekraman village cultural mission. All these characteristics are completely different from banking institutions and are not owned by any bank.

LPD was formed for the purpose of carrying out a cultural mission, only carrying out activities internally - the community, and oriented towards improving the welfare of the Pekraman village community which basically also aims to increase the community's ability to bear the burden of maintaining civilization. The element of profit in the activities of the Village Credit Institution (LPD) is the element of profit in the context of the community's communal mission, namely the development of civilization.

The economic function, which is carried out by the LPD is a domestic economic function, namely the economic function in the Pekraman village "household" for household affairs in the Pekraman village Pemogan. The "household" characteristic of this Pekraman village was born from the provisions of Article 18 B of the 1945 Constitution of the Republic of Indonesia which gave constitutional recognition of indigenous peoples along with their traditional rights. The traditional rights when read in the context of their spirit and soul are the psychology of the 1945 Constitution (original version), which in its explanation emphasizes the recognition of the autonomous "original structure" (special regions). Considering that non-bank LPDs as per the Banking Law were formed for the purpose of regulating banks, while non-bank LPDs so that the rights to ownership and use of the cultural rights of traditional villages to the system socio -cultural properties owned by the LPD are guaranteed by the 1945 Constitution of the Republic of Indonesia and the 1999 Human Rights Law. Furthermore, in the implementation 
of the Pemogan Village Credit Institution, it is also seen that there are LPD money lending by residents of Pemogan Village. Or in other words, there is credit provided by the LPD for villagers who feel they need the credit loan. In implementing the credit provided by the Pemogan LPD, villagers who borrow the minimum credit meet the requirements issued by the

LPD for these residents. In addition, the LPD in carrying out credit must pay attention to the principle of prudence in order to avoid fraudulent actions or actions from both the LPD manager and from residents who transact with the LPD, so that LPD Pemogan can run well, smoothly and be able to prosper the lives of residents' Pemogan Village.

Furthermore, it can be noted about the credit that occurs in the LPD in Pemogan village pay attention to the law. No. 10 of 1998, the definition of credit is a provision of money or an equivalent claim, based on a loan agreement or agreement between the bank and another party which requires the borrower to pay off its debt after a certain period of time with interest. Credit elements, namely creditors (creditors); debtor (credit recipient); trust; deal; period of time; risk. Types of credit based on institution; based on the period of time; based on purpose or use; based on turnover activities; under guarantee; based on the type of credit; based on withdrawals and redemptions; based on how to use it. The classification of performing loans and non-performing loans.

The principle of lending based on the Decree of the Board of Directors of Bank Indonesia no. 27/162 / Kep / Dir dated March 31, 1995, it was stipulated that in the extension of the credit, at least it contained and regulated the main matters as follows the precautionary principle; credit organization and management; credit approval policy; credit documentation and administration; credit supervision; and settlement of problem loans. The cause of bad credit (error omission (EO) is caused by an element of intent to violate the policies and procedures that have been set; Error omission, the emergence of bad credit due to taking advantage of weak regulations or provisions, namely that they do not exist or already exist but are not clear. In this case, legal problems arise because of bad credit or by means of salvage and settlement of bad credit, rescheduling, namely changes in credit terms that only concern the payment schedule and / or time period; reconditioning, namely changes in part or all of the credit terms which is not limited to changes in payment schedules, time periods, and / or other requirements, as long as it does not involve a maximum credit balance; restructuring, namely changes in credit terms including rescheduling, reconditioning; and adding credit facilities: for example by dividing additional payments small so not burdensome consumers. Credit rescue, namely by converting arrears into new loan principal. This will allow the debtor to pay credit and pay the interest in back so that it is not heavy; interest exemption from debtors; pledge pledged goods; play with the collector, just remind it without violence; tighten re-estimates of potential credit repayment capacity. The steps of the bank in dealing with bad credit are:

a. The process of gathering information: a) the relationship between the bank and the customer, to find out which potential customers are invited to work together to solve bad credit problems; b) management potential: the bank studies the potential of customers in managing their finances in the future, observing the development of their business; c) financial reports: banks study financial reports prepared by customers, which are conducted to analyze the causes of bad credit; d) the strengths and weaknesses of the bank from a legal perspective: apart from information relating to credit, the bank will also study the strength of the bank from a legal perspective, so that there is no wrong step in determining actions; e). customer strength in law: the bank will also study the strength of the customer in law, so as not to put the bank in a difficult position; and f). Other creditor positions, the bank needs to study the position of other creditors relating to assets business, 
so that when it is necessary to sell assets to pay off bank credit installments, there will be no difficulties.

b. analysis Problem: a) the next step for the bank is to consider whether the problem can be resolved without legal means that could damage good relations with customers; b) if based on information search it is found that the customer is fraudulent and is not cooperative with the bank, then the bank will firmly bring the problem of bad credit to the legal table.

There are two ways to resolve bad debts, namely (1) namely non-litigation actions. It is also called a workout, which is settlement with communication in order to provide understanding between the bank and the customer to save the customer's business activity. There are 3 ways to work out, namely rescheduling, reconditioning, and restructuring. (2) Litigation actions. If the bank feels the need to bring the problem of bad credit to court, action can be taken in several ways including: a) through a district court, on the legal basis of article 1131 of the Civil Code, in which all customer assets will become debt collateral for the bank; b) through a commercial court, a bank customer filed for bankruptcy; c) report to the police if the bank finds fictitious data when collecting information from customers. Based on the implementation of lectures and assistance to LPD customers who experience bad credit, an agreement was made that out of 10 customers 7 of them agreed to pay off the credit by extending the installment time. This agreement is also a solution for the LPD in overcoming bad credit.

\subsection{Cooperative Bodies The}

Existence of a cooperative legal entity in Pemogan Village can also help improve the economic life of every member of the Pemogan Village community. Cooperative comes from the words "Co" and "Operation" which means working together to achieve goals. Therefore, in general, Arifin Chaniago states that a cooperative is "an association whose members are people or bodies that provide freedom of entry and exit as members by cooperating in a family manner to carry out efforts to enhance the welfare of its members".

In Indonesia, cooperatives are regulated in Law no. 25 of 1992 concerning Cooperatives, in lieu of Law No. 12 of 1967. The Cooperative Law, Article 1 letter 1, states that a cooperative is a "business entity whose members are people or cooperative legal entities which base their activities on the principles of cooperatives as well as a people's economic movement based on the principle of kinship". Cooperatives must be legal entities. This is done by having a cooperative establishment deed and legalized by the government, which then the establishment deed must be announced in the Supplement to the State Gazette (Articles 9 to 14 of Law No. 25 of 1992). Benefits of cooperatives, among others:

a. Build and develop the potential and economic capacity of members in particular and society in general to improve their economic and social welfare.

b. Take an active role in enhancing the quality of human life and society.

c. Strengthening the strength and resilience of the national economy with cooperatives as the mainstay of teachers.

d. Trying to create and develop together based on the principles of kinship and economic democracy.

In the implementation of Cooperatives, have principles, namely: a) membership is voluntary and open; b) management is carried out in a democratic manner; c) distribution of the remaining operating income shall be carried out fairly and in proportion to the amount of business services of each member; d) providing limited business remuneration for capital; and e) independence. 
Furthermore, it can be noted the procedures for establishing cooperatives, including the Formation Meeting, this meeting can only be held by a minimum of 20 prospective members. In the meeting, what needs to be decided is the deed of establishment and articles of association of the cooperative. Second, the application for ratification, is carried out in writing by the founders to the government $(\mathrm{Cq}$. The department that fosters cooperatives is now the minister of cooperatives and OKM), by attaching; a) minutes of the formation meeting; b) deed of establishment; c) articles of association. Ratification must have been made by the government no later than 3 months after receipt of the application by publishing it in the State Gazette of the Republic of Indonesia.

\section{Conclusion}

Based on the results of the implementation of community service activities in Pemogan Village by the Master of Notary (MKN) Study Program, Warmadewa University. The following conclusions can be made:

a. Settlement of problem loans in LPD practice in Pemogan Village, begins with negotiations between the LPD manager and Pemogan Village community members. The problem is, then a solution is found for the middle way of solving the problems faced by the villagers, so that the problems between the residents and the LPD can be resolved. Seven out of 10 LPD customers who attended agreed to pay off their credit by extending the installment time.

b. The benefits of a cooperative for the citizens of Pemogan Village, namely being able to improve the quality of life of the Pemogan Village community, as well as being able to build and develop the economic potential and capacity of each member, so that they can live prosperously.

\section{References}

[1] Alves, W., Ferreira, P., \& Araújo, M. (2019). Mining co-operatives: A model to establish a network for sustainability. Journal of Co-Operative Organization and Management, 7(1), 51-63. https://doi.org/10.1016/j.jcom.2019.03.004

[2] Borda-Rodriguez, A., \& Vicari, S. (2014). Rural co-operative resilience: The case of Malawi. Journal of Co-Operative Organization and Management, 2(1), 43-52. https://doi.org/10.1016/j.jcom.2014.03.002

[3] Czekaj, M., Adamsone-Fiskovica, A., Tyran, E., \& Kilis, E. (2020). Small farms' resilience strategies to face economic, social, and environmental disturbances in selected regions in Poland and Latvia. Global Food Security, 26, 100416. https://doi.org/10.1016/j.gfs.2020.100416

[4] Hayter, R., \& Nieweler, S. (2018). The local planning-economic development nexus in transitioning resource-industry towns: Reflections (mainly) from British Columbia. $\begin{array}{lllll}\text { Journal of Rural } & \text { Studies, } & \text { 60(April 2017), }\end{array}$ https://doi.org/10.1016/j.jrurstud.2018.03.006

[5] Pomeroy, R., Arango, C., Lomboy, C. G., \& Box, S. (2020). Financial inclusion to build economic resilience in small-scale fisheries. Marine Policy, 118(September 2019), 103982. https://doi.org/10.1016/j.marpol.2020.103982 